\title{
PERBANDINGAN FUZZY AHP-SAW DENGAN FUZZY AHP-VIKOR UNTUK MENINGKATKAN DAYA SERAP POLITEKNIK TERHADAP INDUSTRI
}

\author{
Nawindah', Dani Anggoro² \\ Fakultas Teknologi Informasi ${ }^{1,2}$ \\ Universitas Budi Luhur \\ J1. Raya Ciledug, Petukangan Utara, Jakarta Selatan, 12260 \\ nawindah@budiluhur.ac.id, dani.anggoro@budiluhur.ac.id
}

\begin{abstract}
Abstrak
Peningkatan daya serap Politeknik terhadap industri sangat dipengaruhi oleh lulusannya salah satunya dipengaruhi oleh pemilihan jurusan yang merupakan awal untuk menciptakan mahasiswa yang ahli dibidangnya. Penentuan kriteria, subkriteria dan alternatif menggunakan Cochran $Q$ Test. Untuk mendapatkan bobot digunakan metode Analytic Hierarchy Process (AHP). Kriteria yaitu jurusan sekolah asal, subkriteria yaitu IPA, IPS, AK, PJ/PM. Kriteria hasil tes bakat minat yaitu sanguinis, melankolis, korelis dan plegmatis. Alternatif diantaranya Computerized Accounting (CA), Office Management (OM), Informatics Computer (IC). Pada pemilihan jurusan ini peneliti membandingkan metode yang sesuaidengan Fuzzy Multi Attribute Decision Making metode Analytic HierarchyProcess (AHP)- Simple Additive Weighting (SAW) dan metode Analytic Hierarchy VIKOR (Visekriterijumsko Kompromisno Rangiranje). Daya serap terhadap industri menggunakan metode deskriptif dengan alat ukur service quality hasilnya industri puas terhadap lulusan yang berkerja pada industri baik dari hardskill dan softskill. Metode Fuzzy AHP-SAW urut peringkat 1,2 dan 3 yaitu alternatif IC dengan nilai V1 1.76144, alternatif CA dengan nilai V2 $=1.56974$, alternatif V3 dengan nilai $\mathrm{OM}=1.33618$. Menggunakan metode Fuzzy AHP-VIKOR dengan urut peringkat 1 sampai 3 yaitu alternatif IC dengan nilai $\mathrm{Q} 1=0$, alternatif $\mathrm{CA}$ dengan nilai $\mathrm{Q} 2=1$, alternatif $\mathrm{OM}$ dengan nilai $\mathrm{Q} 3=1$. Kedua metode tersebut dapat digunakan untuk rekomendasi pemilihan jurusan untuk politeknik LP3I kampus Karang Tengah.
\end{abstract}

Kata kunci : Pemilihan jurusan, Fuzzy AHP-SAW, Fuzzy AHP-VIKOR

\section{Abstract}

Increasing the absorption of the Polytechnic towards the industry is very important by universities, one of which is the result of the selection of majors which is the beginning to make students who are experts in their fields. Determination of criteria, sub-criteria and alternatives using the Cochran Q Test. To get the weight used Analytic Hierarchy Process (AHP) method. The criteria are the school of origin, subcriteria namely Natural Sciences, Social Sciences, $A K, P J$ / PM. The criteria for competency test results of interest are sanguinis, melancholy, korelis and plegmatis. Computerized Alternative Accounting (CA), Office Management (OM), Computer Information (IC). In this selection, the researchers compared the methods that corresponded to the Fuzzy Multi Attribute Decision Making Analytic Hierarchy Process (AHP) - Simple Additive Weighting (SAW) method and the VIKOR Analytic Hierarchy (Visekriterijumsko Kompromisno Rangiranje) method. Absorption of the industry using descriptive methods with measuring instruments the quality of industrial output is satisfied with the results that work in the industry both from hard skills and soft skills. The AHP-SAW Fuzzy Method, ranked 1.2 and 3, is an alternative IC with a value of VI 1.76144, an alternative $C A$ with a value of $V 2=1.56974$, alternative V3 with an OM value of 1.33618. Using the Fuzzy AHP-VIKOR method in order of rank 1 to 3 namely alternative ICs with a value of $Q 1=0$, alternative CAs with a value of $Q 2=1$, alternative $O M$ with a value of $Q 3=1$. This second method can be used to approve the selection of majors for the campus LP3I polytechnic Central Coral.

Keywords: Major selection, Fuzzy AHP-SAW, Fuzzy AHP-VIKOR 


\section{Pendahuluan}

Pentingnya minat dalam mencapai kesuksesan dalam berkarier (Vasilescu, C.C., Moraru, A., Sava, N.I., 2015. Memilih jurusan kuliah memprediksi prestasi masa depan (Allen, J., Robbins, S., 2010. ), pendapatan (Berger, 1988), dan kesejahteraan (Jiang, J., Song, Y., Ke, Y., Wang, R., Liu, H., 2016.) Bagi banyak kaum muda, memilih jurusan di perguruan tinggi mungkin merupakan keputusan hidup yang paling penting mereka membuat, karena akan memiliki implikasi mendalam untuk sisa hidup mereka. (Yu, S., Zhang, F., Nunes, L.D., LevesqueBristol, C., 2018). Untuk itu bagian marketing meminta calon mahasiswa untuk mengisi tes bakat minat dan mengisi form data diri, untuk menentukan jurusan. Jurusan yang ada di kampus Politeknik LP3I Kampus Karang Tengah meliputi : Computerized Accounting (CA), Office Management (OM), Informatics Computer (IC).

Cara ini masih memiliki kelemahan, dapat dilihat saat melakukan tes bakat dan minat, mahasiswa mengalami kondisi fisik yang kurang sehat atau mental yang lelah karena faktor jasmani dan psikologi sangat mempengaruhi (Eisenberg, D., Golberstein, E., Hunt, J.B., 2009.), maka akan ada pertanyaan, apakah relevan hasil tes tersebut ? Salah satu mekanisme untuk menyelesaikan masalah tersebut yaitu menggunakan fuzzy MADM dengan metode Analytic Hierarchy Process (AHP) dan Simple Additive Weighting $(S A W)$. Konsep dasar metode $S A W$ adalah mencari penjumlahan terbobot dari rating kinerja pada setiap alternatif pada semua atribut (Fishburn, P.C., 1967).(MacCrimmon, K.R., 1968). Metode SAW membutuhkan proses normalisasi matrik keputusan (X) ke suatu skala yang dapat diperbandingkan dengan semua rating alternatif yang ada. Konsep dasar metode VIKOR (Visekriterijumsko Kompromisno Rangiranje) merupakan teknik pengambilan keputusan yang dikembangkan untuk mengoptimasi permasalahan multikriteria. Indeks rangking multikriteria didasarkan pada kedekatan antar alternatif yang ideal maupun tidak ideal (Opricovic, S., Tzeng, G.H., 2004.)

Berdasarkan uraian diatas, maka didapatkan identifikasi masalah yaitu : Bagaimana perbandingan metode Fuzzy AHP-SAW dan Fuzzy-VIKOR dalam pemilihan jurusan studi kasus Politeknik LP3I Kampus Karang Tengah?. Melakukan perbandingan antara kedua metode sehingga diperoleh rekomendasi metode terbaik.

\section{KAJIAN LITERATUR}

\section{II.1 Seleksi Penerimaan Siswa Baru}

Pemilihan jurusan dilakukan dengan cara : 1. calon mahasiswa melakukan tes bakat minat 2. dengan melihat jurusan sekolah asal. Tujuannya adalah di masa depan, maha siswa lebih terfokus karena telah sesuai dengan minatnya. Selain itu, dalam melakukan pemilihan yang tepat dapat memberikan manfaat seperti pengelompokan siswa sesuai dengan keahlian, kemampuan, bakat, dan minat mereka yang relatif sama, membantu siswa mempersiapkan diri untuk melanjutkan studi dan memilih dunia kerja. Kriteria yang digunakan sebagai pertimbangan, yaitu jurusan sekolah asal : IPA, IPS, AP, AK, PJ/PM, Hasil tes bakat minat : Sanguinis, Melankolis, Korelis dan Plegmatis .

\section{II.2 Decision Support System}

Sistem Pendukung Keputusan Dukungan Sistem (DSS) adalah informasi spesifiksistem yang dimaksudkan untuk membantu manajemen dalam membuat keputusan berkenaan dengan pertanyaan yang semi terstruktur, dan itu tidak menggantikan fungsi pengambil keputusan dalam membuat keputusan yang terinformasi.(M. Kusrini,2007).

\section{II.3 Analytic Hierarchy Process (AHP)}

Proses Hierarki Analitik dikembangkan oleh Dr. Thomas L. Saaty dari Wharton School of Business pada tahun1970-an untuk mengorganisir informasi dan pendapat ahli dalam memilih alternatif yang disukai [Saaty,1983]. Dengan menggunakan AHP , suatu persoalan akan diselesaikan dalam suatu kerangka pemikiran yang terorganisir, sehingga dapat diekspresikan untuk mengambil keputusan yang efektif atas persoalan tersebut. Persoalan yang kompleks dapat disederhanakan dan dipercepat proses pengambilan keputusannya.

\section{II.4 Fuzzy Analytic Hierarchy Process (F-AHP)}

F-AHP menutupi kelemahan yang terdapat pada AHP, yaitu permasalahan terhadap kriteria yang memiliki sifat subjektif lebih banyak. Ketidakpastian bilangan direpresentasikan dengan urutan skala. Penentuan derajat keanggotaan F-AHP yang dikembangkan oleh Chang (1996) menggunakan fungsi keanggotaan segitiga (Triangular Fuzzy Number/TFN). Dengan langkah-langkah metode fuzzy AHP sebagai berikut:

1) Menentukan perbandingan matriks berpasangan antar kriteria dengan skala TFN. 
2) Menentukan nilai Sinstesis fuzzy ( $\mathrm{Si}$ ) Rumus untuk menghitung Si adalah sebagai berikut :

$$
\begin{aligned}
& S i=\sum_{j=1}^{m} M_{i}^{j} \times \frac{1}{\sum_{i=1}^{\mathrm{n}} \sum_{j=1}^{\mathrm{m}} M_{i}^{j}} \\
& \text { dimana } \\
& \sum_{j=1}^{m} M_{i}^{j}=\sum_{j=1}^{m} l_{j}, \sum_{j=1}^{m} m_{j}, \sum_{j=1}^{m} u_{j}
\end{aligned}
$$

Keterangan:

$\mathrm{M}=$ objek (kriteria/subkriteria), $\mathrm{j}=$ indeks ke-j,

$\mathrm{i}=$ indeks ke-i, $\mathrm{g}=$ jumlah kriteria,

$\mathrm{h}=$ jumlah kriteria, $\mathrm{l}=$ lower bound,

$\mathrm{m}=$ middle, $\mathrm{u}=$ upper bound

Menentukan Nilai Vektor (V) Rumus untuk menentukan $\mathrm{V}$ ada pada persamaan dibawah.

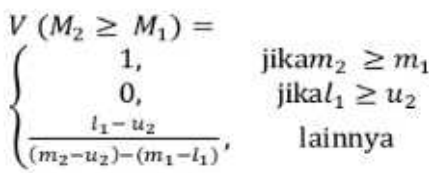

Nilai Ordinat Defuzzifikasi $\left(\mathrm{d}^{\prime}\right)$.Nilai $\mathrm{d}^{\prime}$ didapatkan dengan cara mencari nilai minimal untuk setiap kolom. Normalisasi Bobot Vektor fuzzy. Normalisasi bobot vektor fuzzy dilakukan dengan cara sebagai berikut :

$$
\text { Normalisasi }=\frac{d_{1 j}^{\prime}}{\sum_{j=1}^{m} d_{1 j}^{\prime}}
$$

Hasil yang didapatkan pada proses ini adalah bobot akhir.

\section{II.5 Fuzzy Simple Additive Weighting (SAW)}

Fuzzy Simple Additive Weighting (SAW) digunakan untuk menentukan jurusan yang akan dipilih berdasarkan kriteria dan berat yang telah ditentukan. Metode Simple Additive Weighting (SAW) sering juga dikenal sebagai metode penambahan berbobot. Konsep dasar dari metode SAW adalah untuk menemukan penjumlahan bobot dari peringkat kinerja. Ada setiap alternatif untuk semua atribut. (Fishburn, 1967) (MacCrimmon, 1968). Metode SAW memerlukan proses normalisasi matriks keputusan (X) ke skala yang dapat dibandingkan dengan semua peringkat alternatif yang tersedia. Untuk menghitung atribut manfaat, digunakan rumus seperti dalam Persamaan

$$
r_{i j}=\frac{x_{i j}}{\operatorname{Max} x_{i j}}
$$

Untuk menghitung atribut biaya, digunakan rumus seperti dalam Persamaan

$$
r_{i j}=\frac{\operatorname{Minx}_{i j}}{x_{i j}}
$$

Untuk menghitung nilai preferensi untuk setiap alternatif, digunakan rumus :

$$
\mathrm{V}_{\mathrm{i}}=\sum_{j=1}^{n} \mathrm{w}_{\mathrm{ij}} \mathrm{r}_{\mathrm{ij}}
$$

Langkah-langkahnya adalah:

Langkah 1: Menentukan kriteria yang akan digunakan sebagai referensi dalam pengambilan keputusan, yaitu Ci.

Langkah 2: Menentukan peringkat kecocokan dari masing-masing alternatif pada setiap kriteria.

Langkah 3: Membuat keputusan berdasarkan matriks kriteria (Ci).

Langkah 4: Normalisasi matriks berdasarkan persamaan yang disesuaikan dengan jenis atribut manfaat (atribut atau atribut biaya) sehingga diperoleh matriks ternormalisasi $\mathrm{R}$.

Langkah 5: Hasil akhir diperoleh dari proses peringkat, yaitu, jumlah matriks normalisasi R dengan vektor bobot untuk mendapatkan nilai terbesar yang dipilih sebagai alternatif terbaik (Ai) sebagai solusinya. (Khasanah, F.N., Permanasari, A.E., Suningkusumawardani, S., 2016).

\section{II.6 Visekriterijumsko Kompromisno Rangiranje (VIKOR)}

Dalam penelitian ini, metodologi VIKOR digunakan untuk menyelesaikan permasalahan dengan kriteria yang bertentangan dan tidak sepadan. Berfokus pada peringkat dan pemilihan dari sekumpulan alternatif kriteria untuk mencapai keputusan terakhir. (Nofriansyah, Dicky,2014) Langkah-langkah yang digunakan pada metode VIKOR sebagai berikut :

1) Normalisasi Metrix

$$
R_{i j=}\left(\frac{x j^{+}-X_{i j}}{X j^{+}-X j^{-}}\right)
$$

Keterangan : Rij dan Xij (i=1,2,3, ... m dan $\mathrm{j}=1,2,3, \ldots, \mathrm{n})$ adalah elemen dari matriks pengambilan keputusan (alternatif i terhadap kriteria j) dari $\mathrm{Xj}$ adalah elemen terbaik dari kriteria $\mathrm{j}, \mathrm{X} \mathrm{j}$ adalah elemen terburuk dari kriteria j.

2) Menghitung nilai $S$ dan $R$ menggunakan persamaan

$$
S_{i}=\sum_{j=i}^{n} W_{j}\left(\frac{x_{j}^{+}-x_{i j}}{x_{j}^{+}-x_{j}^{-}}\right)
$$


dan

$$
R_{i}=\operatorname{Max} j\left[W_{j}\left(\frac{x_{j}^{+}-x_{i j}}{x_{j}^{+}-x_{j}}\right)\right]
$$

Dimana $\mathrm{Wj}$ adalah bobot dari tiap kriteria $\mathrm{j}$. Menghitung nilai Alternatif (Qi) dengan menggunakan rumus

$$
Q_{i}\left[\frac{S_{i}-S^{+}}{S^{+}-S^{-}}\right] v+\left[\frac{R_{i}-R^{+}}{R^{+}-R^{-}}\right](1-v)
$$

Dimana $\mathrm{S}-=\min \mathrm{Si}, \mathrm{S}+=\max \mathrm{Si}$ dan $\mathrm{R}-=\min$ $\mathrm{Ri}, \mathrm{R}+=\max \mathrm{Ri}$ dan $\mathrm{v}=0,5$. Hasil perankingan merupakan hasil pengurutan dari S, R dan Q.

\section{AnAlisis dan Perancangan}

\section{III.1 Metodelogi Penelitian}

\section{1) Populasi}

Untuk pemilihan jurusan populasinya adalah mahasiswa reguler angkatan 2013 dengan jurusan Computerized Accounting(CA), Office Management (OM) , Informatics Computer (IC). Jumlah mahasiswa ketiga jurusan tersebut sebanyak 38 mahasiswa LP3I Kampus Karang Tengah.

\section{2) Metode pemilihan sampel}

menurut cara pengambilan data berdasarkan sumbernya adalah data primer dengan memberikan kuesioner kepada Kepala Bidang Studi, Kepala Divisi Marketing, Kepala Bagian Penempatan Kerja dan data sekunder. Proses pemilihan sampel yang digunakan dengan metode sensus . Dengan populasi yang ada sebanyak 38 mahasiswa.

\section{3) Metode Pengumpulan data}

Penelitian yang dilakukan untuk menghasilkan data dan informasi yang diperlukan serta berhubungan dengan hal yang akan ditulis. Untuk mengumpulkan data serta informasi yang diperlukan oleh peneliti menggunakan metode sebagai berikut : Pengumpulan data sekunder Data sekunder peneliti dapatkan dari mengamati data, membaca, mempelajari dan mengutip dari buku literatur, serta sumber-sumber lain yang berhubungan erat dengan penulisan

\section{4) Teknik Analisa Data}

Analisa data yang digunakan dalam pemilihan jurusan adalah analisis kuantitatif, sampel yang digunakan dalam penelitian ini sebanyak 38 data mahasiswa yang akan digunakan dalam pemilihan jurusan.

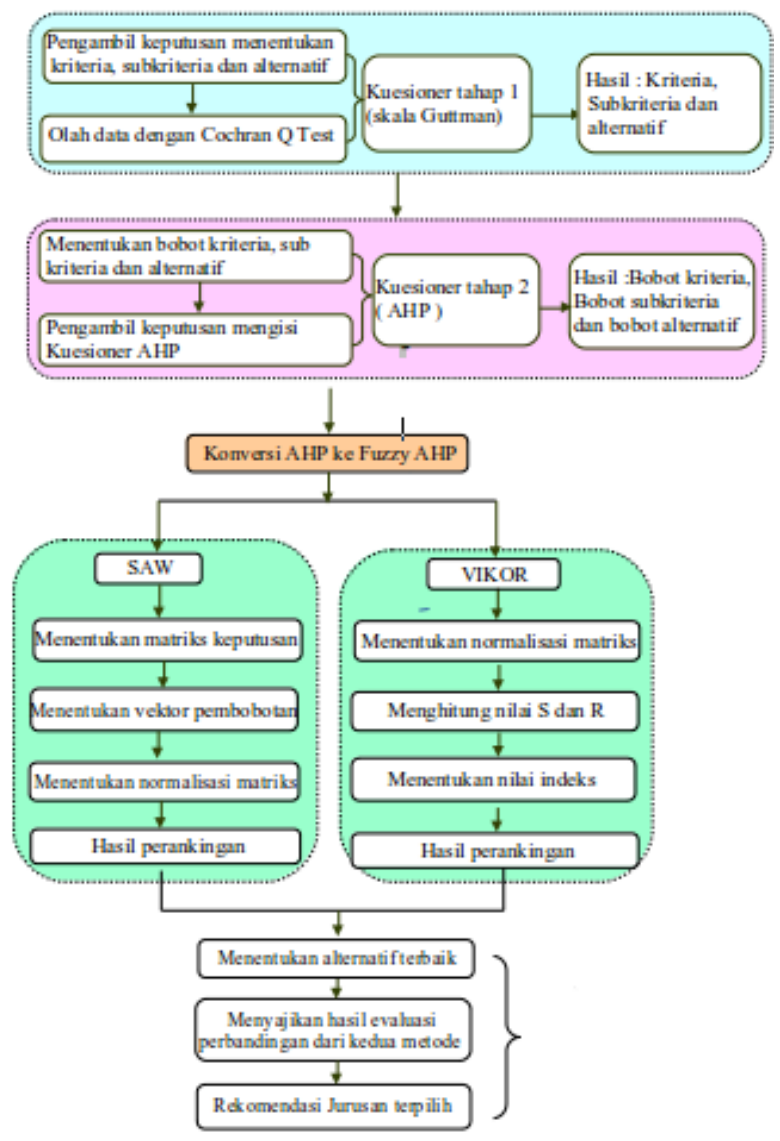

Gambar 3.1. Metodelogi Penelitian

Pada gambar 3.1 terlihat langkah-langkah penelitian yang perlu dilakukan yaitu :

Membuat kuesioner tahap 1 dengan menggunakan skala Guttman , pengambil keputusan akan mengisi kuesioner dengan melakukan cek list atas pertanyaan yang diberikan untuk kemudian akan dilakukan pengolahan data dengan menggunakan Cochran Q Test. Hasil pengolahan data berupa kriteria, subkriteria dan alternatif. Membuat kuesioner Analytical Hierarky Process (AHP) tahap 2, dengan kriteria, subkriteria dan alternatif yang ada .Pengambil keputusan akan melakukan pengisian kuesioner AHP, pengolahan data dilakukan guna mendapatkan bobot dari masing-masing kriteria, subkriteria dan alternatif. Dari hasil pengolahan kuesioner tahap dua dilakukan konversi dari AHP ke fuzzy AHP . Dilakukan perhitungan SAW dan VIKOR, sehingga mendapatkan hasil perankingan 
dari masing-masing metode. Ditentukan alternatif terbaik dan akan dilakukan evaluasi untuk membandingkan kedua metode tersebut. Didapatkan rekomendasi pemilihan jurusan terbaik.

\section{III.2 Hasil dan Pembahasan}

Untuk menentukan elemen-elemen yang signifikan pada masing-masing level dengan menggunakan metode cochran's q test. Berdasarkan hasil uji metode cochran's q test, maka dilakukan kajian dengan menggunakan proses hierarki untuk menjawab rumusan masalah. Kemudian dari hasil data akan dapat memberikan jawaban atas hipotesa yang diajukan pada penelitian ini, sesuai atau tidak sesuai dengan disertai makna empiris dan teoritis. Setelah menyusun hierarki, akan dirancang kuesioner tahap dua untuk melakukan pembobotan terhadap kriteria, subkriteria. Data dari responden akan diolah menggunakan metode fuzzy AHP-SAW dan fuzzy AHP-VIKOR, kemudian dilakukan perbandingan antara kedua metode tersebut.

\section{1) Kuesioner Pendahuluan dengan metode judgement Skala Guttman}

Pada kuesioner pendahuluan dilakukan penyebaran kuesioner tahap pertama kepada 3 (tiga) responden ahli yang akan melakukan pengujian elemen-elemen yang signifikan pada masing-masing level dimulai dari level 1 untuk penentuan kriteria yaitu jurusan sekolah asal dan hasil tes bakat minat, level 2 untuk penentuan sub kriteria yaitu IPA, IPS, AP, AK, PJ/PM ,Sanguinis, Melankolis, Korelis, Plegmatis dan level 3 untuk penentuan alternatif pilihan yaitu OM, CA, IC. Uji validitas yang dilakukan untuk elemenelemen pada masing-masing level dilakukan dengan metode statistic Cochran Q Test, metode ini digunakan untuk mengetahui attribut apa saja yang dianggap sah (valid), dimana peneliti mengeluarkan atribut-atribut yang dinilai tidak sah berdasarkan kriteria-kriteria statistik yang dipakai. Dalam metode ini, responden ahli diberikan pertanyaan tertutup dengan metode Judgement Skala Guttman, yaitu pertanyaan yang pilihan jawabannya terdiri atas YA jika setuju dengan atribut yang diberikan dan TIDAK jika tidak setuju dengan atribut yang diberikan.

\section{2) Kuesioner Tahap Dua}

Pada kuesioner tahap dua ini merupakan kuesioner AHP, dilakukan penyebaran kuesioner kepada 3 (tiga) responden ahli yang akan digunakan untuk pembobotan terhadap kriteria dan sub kriteria.

\section{3) Data Sekunder}

Data sekunder yang diolah merupakan data mahasiswa jurusan sekolah asal, hasil tes bakat minat. Dengan subkriteria untuk jurusan sekolah asal: IPA , IPS, AP, AK,PJ/PM dan sub kriteria hasil tes bakat minat untuk sanguinis, melankolis, korelis dan plegmatis.

\section{4) Hasil Penelitian Kuesioner Pendahuluan}

Kuesioner pendahuluan yang disebarkan untuk responden ahli sebanyak 3 orang dengan jumlah kuesioner dua lembar dan dikembalikan kuesioner tersebut. Berdasarkan dari hasil tanggapan responden ahli terhadap elemen-elemen yang signifikan pada masing-masing level dimulai level I untuk penentuan kriteria, level II untuk penentuan sub kriteria , dan level 3 untuk penentuan alternatif pilihan dengan metode cochran q tes, sebagai berikut :

Atribut kriteria mendapatkan nilai Qhitung sebesar 5 dan Qtab sebesar 6 sehingga sesuai dengan ketentuan Qhit $<$ Qtab maka atribut kriteria sah/valid.

Sub kriteria jurusan sekolah asal mendapatkan nilai Qhitung sebesar 4 dan Qtab sebesar 9,49 maka sub kriteria sah/valid.

Elemen alternatif mendapatkan nilai Qhitung sebesar 7.2 dan Qtab sebesar 7.81 sehingga sesuai dengan ketentuan Qhit < Qtab maka atribut alternatif sah/valid.

\section{5) Hasil Penelitian Kuesioner AHP / Tahap Dua}

Kuesioner ini ditujukan untuk responden ahli dan digunakan untuk mengetahui pemilihan jurusan yang dipilih. Jumlah responden ahli yang terpilih untuk mengisi kuesioner adalah tiga orang. Jumlah kuesioner yang disebarkan untuk responden ahli sebanyak enam lembar untuk tiap responden ahli.

\section{6) Inconsistency Ratio (CR)}

Incossistency ratio atau inkonsistensi data responden merupakan parameter yang digunakan untuk memeriksa apakah perbandingan berpasangan telah dilakukan dengan konsekuen atau tidak.Ratio inkonsistensi dianggap baik jika nilai CR-nya $<=0.1$. Berikut ditampilkan nilai ratio inkonsistensi pada masing-masing matriks perbandingan : 
Tabel 3.1 Rasio inkonsistensi perbandingan antara elemen matriks

\begin{tabular}{clc}
\hline \hline No. & Matriks perbandingan elemen & Nilai CR \\
\hline \hline 1. & $\begin{array}{l}\text { Perbandingan elemen kriteria level } \\
\text { berdasarkan sasaran penentuan jurusan. }\end{array}$ & 0 \\
\hline \hline 2. & $\begin{array}{l}\text { Perbandingan elemen sub kriteria level } 2 \\
\text { berdasarkan Jurusan Sekolah Asal. }\end{array}$ & 0 \\
\hline \hline 3. & $\begin{array}{l}\text { Perbandingan elemen sub kriteria level 2 } \\
\text { berdasarkan Hasil Tes Bakat Minat. }\end{array}$ & 0.03 \\
\hline \hline
\end{tabular}

Bahwa perbandingan berpasangan yang diberikan responden ahli memiliki nilai inkonsistensi yang lebih kecil dari 0.1 sebagai batas maksimum nilai rasio inkonsistensi. Dengan demikian data responden adalah konsisten, sehingga krteria dan sub kriteria yang ada dapat digunakan dalam menganalisis perbandingan pemilihan jurusan menggunakan metode fuzzy AHP-SAW dan fuzzy AHP-VIKOR.

\section{7) Konversi AHP ke Fuzzy AHP}

Untuk melakukan konversi terlebih dahulu melihat tabel konversi AHP ke fuzzy AHP sebagai berikut :

Tabel 3.2 : Nilai yang akan digunakan untuk melakukan konversi dari AHP ke Fuzzy AHP

\begin{tabular}{ccccccc}
\hline \hline $\begin{array}{c}\text { Skala } \\
\text { AHP }\end{array}$ & \multicolumn{2}{c}{ Skala Fuzzy } & \multicolumn{3}{c}{ Invers Skala Fuzzy } \\
\hline \hline 1 & 1 & 1 & 1 & 1 & 1 & 1 \\
\hline \hline 2 & 1 & 2 & 3 & 0.333 & 0.5 & 1 \\
\hline \hline 3 & 2 & 3 & 4 & 0.25 & 0.333 & 0.5 \\
\hline \hline 4 & 3 & 4 & 5 & 0.2 & 0.25 & 0.333 \\
\hline \hline 5 & 4 & 5 & 6 & 0,667 & 0.2 & 0.25 \\
\hline \hline 6 & 5 & 6 & 7 & 0.143 & 0.667 & 0.2 \\
\hline \hline 7 & 6 & 7 & 8 & 0.125 & 0.143 & 0.167 \\
\hline \hline 9 & 7 & 8 & 9 & 0.111 & 0.125 & 0.143 \\
\hline \hline
\end{tabular}

\section{a. Konversi subkriteria jurusan sekolah asal}

Tabel 3.3 : Nilai subkriteria jurusan sekolah asal dengan metode AHP

\begin{tabular}{cccccc}
\hline \hline Subkriteria & IPA & IPS & AP & AK & PJPM \\
\hline \hline IPA & 1.00 & 3.00 & 4.00 & 5.00 & 7.00 \\
\hline \hline IPS & 0.33 & 1.00 & 4.00 & 5.00 & 7.00 \\
\hline \hline AP & 0.25 & 0.25 & 1.00 & 1.00 & 3.00 \\
\hline \hline AK & 0.20 & 0.20 & 1.00 & 1.00 & 4.00 \\
\hline \hline PJ/PM & 0.14 & 0.14 & 0.33 & 0.25 & 1.00 \\
\hline \hline
\end{tabular}

Terlihat pada tabel 3.3 nilai kuesioner tahap 2 , yaitu pembobotan subkriteria yang telah diisi oleh pengambil keputusan. Berikut ini akan ditampilkan hasil konversi ke metode fuzzyAHP pada tabel 3.4 :

Tabel 3.4 : Hasil konversi nilai subkriteria dengan metode AHP ke Fuzzy AHP

\begin{tabular}{|c|c|c|c|c|c|c|c|c|c|c|c|c|c|c|c|c|c|c|}
\hline $\begin{array}{c}\text { subkrit } \\
\text { eria }\end{array}$ & \multicolumn{3}{|c|}{ IPA } & \multicolumn{3}{c|}{ IPS } & \multicolumn{3}{c|}{ AP } & \multicolumn{3}{c|}{ AK } & \multicolumn{3}{c|}{ PJ/PM } & \multicolumn{3}{c|}{ Jumlah } \\
\hline & 1 & m & u & 1 & m & u & 1 & m & u & 1 & m & u & 1 & m & u & 1 & m & u \\
\hline IPA & 1 & 1 & 1 & 2 & 3 & 4 & 3 & 4 & 5 & 4 & 5 & 6 & 6 & 7 & 8 & 16 & 20 & 24 \\
\hline IPS & 0.33 & 0.5 & 1 & 1 & 1 & 1 & 3 & 4 & 5 & 4 & 5 & 6 & 6 & 7 & 8 & 14.3 & 17.5 & 21 \\
\hline AP & 0.2 & 0.25 & 0.333 & 0.2 & 0.25 & 0.33 & 1 & 1 & 1 & 1 & 1 & 1 & 2 & 3 & 4 & 4.4 & 5.5 & 6.667 \\
\hline AR & 0.17 & 0.2 & 0.25 & 0.17 & 0.2 & 0.25 & 1 & 1 & 1 & 1 & 1 & 1 & 3 & 4 & 5 & 5.33 & 6.4 & 7.5 \\
\hline PJPM & 0.13 & 0.14 & 0.167 & 0.13 & 0.143 & 0.17 & 0.25 & 0.33 & 0.5 & 0.2 & 0.25 & 0.33 & 1 & 1 & 1 & 1.7 & 1.869 & 2.167 \\
\hline \multicolumn{10}{|c|}{ Jumlah } \\
\hline \multicolumn{10}{|c|}{}
\end{tabular}

Pada tabel 3.4 terlihat hasil konversinya , adapun tabel yang dijadikan acuan dalam melakukan konversi adalah tabel 3.3.

\section{b. Konversi subkriteria hasil tes bakat minat}

Hasil kuesioner tahap 2 untuk subkriteria hasil tes bakat minat yang telah diisi oleh pengambil keputusan sebagai berikut :

Tabel 3.5 : Nilai subkriteria hasil tes bakat minat dengan metode AHP

\begin{tabular}{ccccc}
\hline \hline Subkriteria & $\begin{array}{c}\text { Sanguinis } \\
(\mathrm{S})\end{array}$ & $\begin{array}{c}\text { Melanko } \\
\text { lis (M) }\end{array}$ & $\begin{array}{r}\text { Ko } \\
\text { relis(K) }\end{array}$ & $\begin{array}{r}\text { Pleg } \\
\text { matis (P) }\end{array}$ \\
\hline \hline Sanguinis (S) & 1.00 & 0.50 & 0.33 & 0.20 \\
\hline \hline Melankolis (M) & 2.00 & 1.00 & 0.33 & 0.25 \\
\hline \hline Korelis(K) & 3.00 & 3.00 & 1.00 & 0.50 \\
\hline \hline Plegmatis (P) & 5.00 & 4.00 & 2.00 & 1.00 \\
\hline \hline jumlah & 11 & 8.5 & 3.667 & 1.95 \\
\hline \hline
\end{tabular}

Dari tabel 3.5 terlihat nilai subkriteria untuk hasil tes bakat minat dengan menggunakan metode AHP langkah selanjutnya adalah melakukan konversi ke
Nawindah, Dani Anggoro

Jurnal Ilmiah Teknologi Informasi Terapan

Volume 6, No 1, 15 Desember 2019 
Fuzzy AHP adapun tabel yang dijadikan acuan dalam melakukan konversi adalah tabel 3.5. Berikut ini ditampilkan hasil konversi ke metode fuzzyAHP pada tabel 3.6 sebagai berikut :

Tabel 3.6: Hasil konversi nilai subkriteria hasil tes bakat minat dengan metode AHP ke Fuzzy AHP

\begin{tabular}{|c|c|c|c|c|c|c|c|c|c|c|c|c|c|c|c|}
\hline \multirow{2}{*}{$\begin{array}{c}\text { Sub } \\
\text { kriteria }\end{array}$} & \multicolumn{3}{|c|}{ s } & \multicolumn{3}{|c|}{ M } & \multicolumn{3}{|c|}{$\mathrm{K}$} & \multicolumn{3}{|c|}{$\mathrm{P}$} & \multicolumn{3}{|c|}{ Jumlah } \\
\hline & 1 & $\mathrm{~m}$ & u & 1 & $\mathrm{~m}$ & u & 1 & $\mathrm{~m}$ & u & 1 & $\mathrm{~m}$ & u & 1 & $\mathrm{~m}$ & u \\
\hline $\mathrm{s}$ & 1 & 1 & 1 & 0.33 & 0.5 & 1 & 0.25 & 0.33 & 0.5 & 0.16 & 0.2 & 0.2 & \begin{tabular}{|l|l|}
1.75 \\
\end{tabular} & 2.03 & 2.75 \\
\hline $\mathrm{M}$ & 1 & 2 & 3 & 1 & 1 & 1 & 0.25 & \begin{tabular}{|l|l|} 
& \\
\end{tabular} & 0.5 & 0.2 & 0.25 & 0.3 & 2.45 & 3.58 & 4.83 \\
\hline $\mathrm{K}$ & 2 & 3 & 4 & 2 & 3 & 4 & 1 & 1 & 1 & 0.33 & 0.5 & 1 & 5.33 & 7.5 & 10 \\
\hline P & 4 & 5 & 5 & 3 & 4 & 5 & 1 & 2 & 3 & 1 & 1 & 1 & 9 & 12 & 15 \\
\hline
\end{tabular}

Rating kecocokan dari setiap alternatif pada setiap kriteria-kriteria

Tabel 3.7 Tabel rating kecocokan dari setiap alternatif pada setiap kriteria-kriteria

\begin{tabular}{|c|c|c|c|c|c|c|c|c|c|}
\hline $\begin{array}{c}\text { Alter- } \\
\text { natif }\end{array}$ & \multicolumn{10}{|c|}{ Subkriteria } \\
\cline { 2 - 11 } & IPA & IPS & AP & AK & PJ/PM & S & M & K & P \\
\hline OM & 0 & 0.375 & 0 & 0 & 0 & 0 & 0.149 & 0.152 & 0.120 \\
\hline CA & 0.5 & 0.251 & 0 & 0 & 0 & 0 & 0.0340 & 0.285 & 0.1200 \\
\hline IC & 0.5 & 0.375 & 0 & 0 & 0 & 0 & 0.1494 & 0.152 & 0.0928 \\
\hline
\end{tabular}

Bobot preferensi sebagai berikut :

$$
\mathrm{W}=(0.5,0.5,0,0,0,0,0.33,0.33,0.33)
$$

Berikut ini adalah matriks keputusan yang dibentuk dari tabel kecocokan sebagai berikut :

$$
\mathrm{X}=\begin{array}{ccccccccc}
0 & 0.375 & 0 & 0 & 0 & 0 & 0.14949 & 0.15224 & 0.12006 \\
0.5 & 0.251 & 0 & 0 & 0 & 0 & 0.03401 & 0.28516 & 0.12006 \\
0.5 & 0.375 & 0 & 0 & 0 & 0 & 0.14949 & 0.15224 & 0.09287
\end{array}
$$

Lakukan normalisasi matriks $\mathrm{X}$ berdasarkan persamaan 2 berikut,sehingga diperoleh matriks ternormalisasi $\mathrm{R}$ dengan persamaan 3 sebagai berikut:

$$
R=\begin{array}{lllllllll}
0 & 1 & 0 & 0 & 0 & 0 & 1 & 0.53387 & 1 \\
1 & 0.669 & 0 & 0 & 0 & 0 & 0.22751 & 1 & 1 \\
1 & 1 & 0 & 0 & 0 & 0 & 1 & 0.53387 & 0.77353
\end{array}
$$

Proses pemeringkatan diperoleh berdasarkan persamaan 4 ,berikut hasil pemeringkatan alternatif dengan metode fuzzyAHP-SAW : V1 $(\mathrm{OM})=1.33618$, $\mathrm{V} 2(\mathrm{CA})=1.56974$ dan V3(IC) $=1,76144$. Nilai terbesar ada pada V3, sehingga alternatif jurusan IC adalah alternatif yang terpilih sebagai alternatif terbaik.

\section{8) Perhitungan Fuzzy AHP-VIKOR}

Berikut ini adalah bobot subkriteria $=(0.5,0.5,0,0$, $0,0,0.33,0.33,0.33)$. Berdasarkan hasil penilaian responden berikut penilaian alternatifnya:

Tabel 3.8 Penilaian alternatif terhadap subkriteria

\begin{tabular}{|l|l|l|l|l|l|l|l|l|l|}
\hline \multirow{2}{*}{$\begin{array}{l}\text { Alter- } \\
\text { natif }\end{array}$} & \multicolumn{6}{|l|}{ Sublriteria } \\
\cline { 2 - 9 } & IPA & IPS & AP & AK & PJ/PM & S & M & K & P \\
\hline OM & 0 & 0.375 & 0 & 0 & 0 & 0 & 0.14949 & 0.15224 & 0.12006 \\
\hline CA & 0.5 & 0.251 & 0 & 0 & 0 & 0 & 0.03401 & 0.28516 & 0.12006 \\
\hline IC & 0.5 & 0.375 & 0 & 0 & 0 & 0 & 0.14949 & 0.15224 & 0.09287 \\
\hline
\end{tabular}

Berdasarkan tabel tersebut dilakukan normalisasi nilai alternatif pada setiap subkriterianya dengan menggunakan persamaan 5 . Berikut ini akan dilakukan normalisasi dari tabel 3.8 dengan melakukan perkalian bobot kriteria, sebagai berikut :

Tabel 3.9 : Nilai alternatif metode VIKOR

\begin{tabular}{|l|l|l|l|l|l|l|l|l|l|}
\hline \multirow{2}{*}{$\begin{array}{l}\text { Alter- } \\
\text { natif }\end{array}$} & \multicolumn{6}{|l|}{ Subkriteria } \\
\cline { 2 - 10 } & IPA & IPS & AP & AK & PJ/PM & S & M & K & P \\
\hline OM & 1 & 0 & 0 & 0 & 0 & 0 & 0 & 1 & 0 \\
\hline CA & 0 & 1 & 0 & 0 & 0 & 0 & 1 & 0 & 0 \\
\hline IC & 0 & 0 & 0 & 0 & 0 & 0 & 0 & 1 & 1 \\
\hline
\end{tabular}

Terlihat hasil perkalian dari delapan subkriteria yang ada , selanjutnya akan dilakukan perhitungan nilai $S$ dan $\mathrm{R}$ dari masing-masing alternatif dengan menggunakan persamaan 6 dan 7, berikut ini adalah tabel $\mathrm{S}$ dan $\mathrm{R}$ dari data sampel alternatif sebagai berikut :

Tabel 3.10: Nilai $S$ dan $R$ metode VIKOR

\begin{tabular}{ccc}
\hline \hline Alternatif & \multicolumn{2}{c}{ Nilai } \\
\cline { 2 - 3 } & $\mathrm{S}$ & $\mathrm{R}$ \\
\hline \hline $\mathrm{OM}$ & 0.833 & 0.5 \\
\hline \hline $\mathrm{CA}$ & 0.833 & 0.5 \\
\hline \hline $\mathrm{IC}$ & 0.666 & 0.333 \\
\hline \hline
\end{tabular}

Pada tabel diatas terdapat nilai terbesar untuk $\mathrm{S}=$ 0.833 , nilai terkecil untuk $S=0.666$ dan nilai terbesar $\mathrm{R}=0.5$ dan nilai terkecil $\mathrm{R}=0.333$. Langkah selanjutnya yaitu menghitung nilai indeks VIKOR dengan persamaan 8, nilai $Q$ terkecil adalah nilai terbaik berikut ini adalah nilai indeks VIKOR :
Nawindah, Dani Anggoro

Jurnal Ilmiah Teknologi Informasi Terapan

Volume 6, No 1, 15 Desember 2019 
Tabel 3.11 Nilai peringkat indeks VIKOR

\begin{tabular}{cc}
\hline \hline Alternatif & Nilai (Q) \\
\hline \hline OM & 1 \\
\hline \hline CA & 1 \\
\hline \hline IC & 0 \\
\hline \hline
\end{tabular}

Dari tabel diatas diperoleh alternatif 3 jurusan IC memiliki indeks VIKOR terkecil yaitu 0 , sehingga alternatif IC merupakan ranking 1 dalam proses penyelesaian metode VIKOR ini .

\section{9) PeRbandingan Metode FuzzY AHP-SAW DENGAN FUZZY AHP-VIKOR}

Dari hasil perhitungan dengan metode Fuzzy AHPSAW dengan Fuzzy AHP-VIKOR sebagai berikut :

a) Fuzzy AHP-SAW

Tabel 3.12 Peringkat alternatif dengan metode fuzzy AHP-SAW

\begin{tabular}{ccc}
\hline \hline Alternatif & Nilai (V) & Peringkat \\
\hline \hline OM & 1.33618 & 3 \\
\hline \hline CA & 1.56974 & 2 \\
\hline \hline IC & 1,76144 & 1 \\
\hline
\end{tabular}

Terlihat jurusan Informatic Computer (IC) mendapatkan urutan pertama , diikuti dengan Computer Accountancy (CA) urutan kedua dan Office Management (OM) urutan ketiga.

b) Fuzzy AHP-VIKOR

Tabel 3.13 Peringkat alternatif dengan metode fuzzy AHP-VIKOR

\begin{tabular}{ccc}
\hline \hline Alternatif & Nilai $(\mathrm{Q})$ & Peringkat \\
\hline \hline OM & 1 & 2 \\
\hline \hline CA & 1 & 2 \\
\hline \hline IC & 0 & 1 \\
\hline \hline
\end{tabular}

Terlihat jurusan Informatic Computer (IC) mendapatkan urutan pertama, iikuti dengan Computer Accountancy (CA), Office Management (OM) urutan kedua.

c) Perbandingan metode fuzzy AHP-SAW dengan fuzzy AHP-VIKOR
Tabel 3.14 Perbandingan metode Fuzzy AHP-SAW dengan Fuzzy AHP-VIKOR

\begin{tabular}{cc}
\hline \hline Metode & Peringkat Alternatif \\
\hline \hline Fuzzy AHP-SAW & IC $>\mathrm{CA}>\mathrm{OM}$ \\
\hline \hline Fuzzy AHP-VIKOR & IC $>\mathrm{CA}=\mathrm{OM}$ \\
\hline \hline
\end{tabular}

Dari tabel tersebut dapat dilihat bahwa dengan menggunakan metode Fuzzy AHP-SAW dan metode Fuzzy AHP-VIKOR alternatif terbaik adalah sama ,yaitu Informatic Computer (IC), tetapi untuk urutan berikutnya ada perbedaan. Dari perbandingan ini peneliti dapat merekomendasikan untuk pemilihan jurusan.

\section{KESIMPULAN DAN SARAN}

Dari hasil penelitian yang diperoleh dapat disimpulkan sebagai berikut :

a. Perbandingan menggunakan metode Fuzzy AHPSAW yaitu IC $>$ CA $>$ OM dan metode Fuzzy AHP VIKOR yaitu IC $>\mathrm{CA}=\mathrm{OM}$ alternatif terbaik adalah sama, yaitu Informatic Computer (IC), tetapi untuk urutan berikutnya ada perbedaan. $\mathrm{n}$

b. Menggunakan metode Fuzzy AHP-SAW urut peringkat 1,2 dan 3 yaitu alternatif IC dengan nilai V1 1.76144, alternatif CA dengan nilai $\mathrm{V} 2=1.56974$, alternatif $\mathrm{V} 3$ dengan nilai $\mathrm{OM}$ $=1.33618$. Menggunakan metode Fuzzy AHPVIKOR dengan urut peringkat 1 sampai 3 yaitu alternatif IC dengan nilai $\mathrm{Q} 1=0$, alternatif $\mathrm{CA}$ dengan nilai $\mathrm{Q} 2=1$, alternatif $\mathrm{OM}$ dengan nilai $\mathrm{Q} 3=1$.

c. Kedua metode tersebut dapat digunakan untuk rekomendasi pemilihan jurusan untuk politeknik LP3I kampus Karang Tengah.

\section{REFERENSI}

Khasanah, F.N., Permanasari, A.E., Suningkusumawardani, S., 2016. Fuzzy MADM for major selection at senior high school, in: ICITACEE 2015 - 2nd International Conference on Information Technology, Computer, and Electrical Engineering: Green Technology Strengthening in Information Technology, Electrical and Computer Engineering Implementation, Proceedings. Institute of Electrical and Electronics Engineers Inc., pp. 
$41-45$.

doi:10.1109/ICITACEE.2015.7437767

Cleophas T.J., Zwinderman A.H. (2016) Repeated Measures Binary Data (Cochran's Q Test), (139 Patients). In: SPSS for Starters and 2nd Levelers. Springer, Cham

Chang, D.-Y., 1996. Applications of the extent analysis method on fuzzy AHP. European Journal of Operational Research 95, 649655. doi:10.1016/0377-2217(95)00300-2

Cochran's Q Test, n.d. , in: Encyclopedia of Public Health. Springer Netherlands, Dordrecht, pp. 130-130. doi:10.1007/978-1-4020-56147_440

Deni, W., Sudana, O., Sasmita, A., 2013. Analysis and Implementation Fuzzy Multi-Attribute Decision Making SAW Method for Selection of High Achieving Students in Faculty Level. International Journal of Computer Science Issues 10, 674-68

Eisenberg, D., Golberstein, E., Hunt, J.B., 2009. Mental Health and Academic Success in College. The B.E. Journal of Economic Analysis \& Policy 9, 1-40. doi:10.2202/1935-1682.2191

Engel, M.M., Utomo, W.H., Purnomo, H.D., Kristen, U., Wacana, S., 2017. Fuzzy Multi Attribute Decision Making-Simple Additive Weighting (MADM - SAW) for Information Retrieval (IR) in E - Commerce Recommendation 6, 136-145

Fishburn, P.C. (1967). Additive Utilities with Incomplete Product Set: Applications to Priorities and Assignments. American Society of Operations Research (ORSA), Baltimore, MD, U.S.A.Miller

Hartaji, R.D.A., 2012. Motivasi Berprestasi Pada Mahasiswa Yang Berkuliah Dengan Jurusan Pilihan Orang Tua 5

http://kopertis9.or.id/xdoc/nfile/news/2ca25-25-mei2016-sosialisasi-sn-dikti-2016 bandung(1).pdf [Diakses 12 Nov 2017]

http://belmaHYPERLINK

"http://belmawa.ristekdikti.go.id/2016/08/26/ panduan-penyusunan-kurikulum-pendidikan- tinggi/"wa.ristekdikti.go.id/2016/08/26/pand uan-penyusunan-kurikulum-pendidikantinggi/ [Diakses 18 Nov 2017]

Khasanah, F.N., Permanasari, A.E., Suningkusumawardani, S., 2016. Fuzzy MADM for major selection at senior high school, in: ICITACEE 2015 - 2nd International Conference on Information Technology, Computer, and Electrical Engineering: Green Technology Strengthening in Information Technology, Electrical and Computer Engineering Implementation, Proceedings. Institute of Electrical and Electronics Engineers Inc., pp. 41-45.

doi:10.1109/ICITACEE.2015.7437767

MacCrimmon, K.R., 1968. Decision making among multiple-attribute alternatives: A Survey and Consolidated Approach. Arpa Order

Mikhailov, L., Tsvetinov, P., 2004. Evaluation of services using a fuzzy analytic hierarchy process. Applied Soft Computing Journal 5, 23-33. doi:10.1016/j.asoc.2004.04.001

Nofriansyah, Dicky.Multi Criteria Decision Making (MCDM) pada Sistem Pendukung Keputusan, Deepublish, Yogyakarta, 2014.

Radhakrishnan, R., Kalaichelvi, A., 2014. Selection of the Best School for the Children- a Decision Making Model Using Extent Analysis Method on Fuzzy Analytic Hierarchy Process. International Journal of Innovative Research in Science, Engineering and Technology 3, 12334-12344

Roy, B. (1968). Classement et choix en présence de points de vue multiples (la méthode ELECTRE). RIRO,2, 57-75

Saaty, T.L., 2008. Decision making with the analytic hierarchy process. International Journal of Services Sciences 1, 83. doi:10.1504/IJSSCI.2008.017590

Siswoyo, Dwi. (2007). Ilmu Pendidikan. Yogyakarta: UNY Press

Sun, L., Ma, Z., Shang, Y., Liu, Y., Yuan, H., Wu, G., 2016. Research on multi-attribute decision-making in condition evaluation for power transformer using fuzzy AHP and modified weighted averaging combination. 
IET Generation, Transmission and Distribution 10, 3855-3864. doi:10.1049/ietgtd.2016.0381

Sobel, D.M., Kushnir, T., 2006. The importance of decision making in causal learning from interventions. Memory \& cognition 34, 411419. doi:10.3758/BF03193418

Tyagi, K., Sharma, A., 2016. Ranking of components for reliability estimation of CBSS using fuzzy TOPSIS. International Journal of Systems Assurance Engineering and Management 7, 41-49. doi:10.1007/s13198-014-0287-5

Undang-Undang Republik Indonesia Tentang Sistem pendidikan Nasional Nomor 20 Tahun 2003

Opricovic, S. dan Tzeng, G. (2004), 'Compromise Solution by MCDM Methods a COmparative Analisys of VIKOR and TOPSIS', European Journal of Operational Research 156, 445455.

Parasuraman, A., Zeithaml, V.A., Berry, L.L., 1985. A Conceptual Model of Service Quality and Its Implications for Future Research. Journal of Marketing 49, 41. doi:10.2307/1251430

Prasad, K.G.D., Prasad, M.V., Rao, S.V.V.B., Patro, C.S., 2016. Supplier Selection through AHPVIKOR Integrated Methodology. SSRG International Journal of Industrial Engineering.

William J. Platt, (1970) "Educating for development", , Vol. 12 Issue: 8, pp.296301, $\quad \mathrm{https} / / /$ remotelib.ui.ac.id:4611/10.1108/eb001621

W. Edward Back, Steve R. Sanders, (1998) "Industry expectations for engineering graduates",, Vol. 5 Issue: 2, pp.137-143, https://remote-

lib.ui.ac.id:4611/10.1108/eb021068

Yusuf,Syamsu. (2012). Psikologi Perkembangan Anak dan Remaja. Bandung: Remaja Rosdakarya.diakse tgl 04 Januari 2017.

Yoon, K., 1989. The propagation of errors in multiple-attribute decision analysis: A practical approach. Journal of the
Operational Research Society 40, 681-686. doi:10.1057/jors.1989.111

Zadeh, L. a., 1965. Fuzzy sets. Information and Control 8, 338-353. doi:10.1016/S00199958(65)90241-X. 